\title{
Noves perspectives entorn de la producció de vi de l'ager de Tarraco en època romano-republicana: les produccions amforals de la figlina del Vilar (Valls, Tarragona)
}

\author{
New perspectives on the export of wine from the Ager \\ Tarraconensis in Roman Republican times: the amphora \\ production of the figlina of El Vilar (Valls, Tarragona)
}

\author{
Enric Colom Mendoza \\ Institut Català d'Arqueologia Clàssica \\ Plaça Rovellat, s/n, E-43003 Tarragona \\ ecolom@icac.cat
}

La terrisseria del Vilar fou descoberta durant una intervenció arqueològica d'urgència l'any 2000. L'excavació proporcionà un nivell d'abocador molt interessant, en el qual es documentaren imitacions d'àmfores de tipologia ja plenament romana, com seria la grecoitàlica i la Dressel 1A, així com àmfores ovoides de reduïdes dimensions. A partir de l'observació dels fragments amforals de la UE 4018 del Vilar, hem portat a terme l'estudi morfològic de les formes documentades, així com la caracterització a nivell macroscòpic de les pastes ceràmiques locals. Es tracta d'una fita important en el coneixement de l'explotació vitivinícola a l'ager Tarraconensis per a la seva exportació, ja que es tracta de la terrisseria d'àmfores romanes més antiga documentada a la Provincia Hispania Citerior, la qual va iniciar-ne la producció en algun moment del segon quart del segle II aC.

\section{PARAULES CLAU}

FIGLINAE, AGER TARRACONENSIS, ÀMFORES ROMANO-REPUBLICANES, ÀMFORES PARVAE

The kiln of El Vilar was discovered in 2000 during an archaeological survey. The excavation provided a very interesting dump of waste material where imitations of amphorae of fully Roman types were documented, notably the Greco-Italic and Dressel 1A, as well as small module versions of ovoid amphorae. Based on the study of amphora fragments from stratigraphic unit 4018 of El Vilar, we have carried out the typological study of the documented amphoras, as well as the macroscopic characterization of the local fabrics. This provides key new data on the exploitation of wine for export produced in the ager Tarraconensis, this being the oldest Roman figlina documented in the Provincia Hispania Citerior, with its earliest phase of production dating to within the second quarter of the 2 nd century BC.

\section{KEYWORDS}

FIGLINAE, AGER TARRACONENSIS, ROMAN-REPUBLICAN AMPHORAS, PARVAE AMPHORAS 


\section{Introducció. El jaciment del Vilar de Valls}

La vil-la romana del Vilar es troba al sud-est del terme municipal de Valls, capital de la comarca tarragonina de l'Alt Camp. És en aquest indret on es localitza el poblat ibèric del Vilar, que ocupa una àrea aproximada d'uns $60.000 \mathrm{~m}^{2}$, sobre una petita elevació de terreny $(230 \mathrm{msnm}$ ) vorejada per dos barrancs, un dels quals amb un curs constant d'aigua. Per les grans dimensions que presenta aquest poblat indígena, se l'ha de considerar com el segon més extens de la Cessetània, només superat per Cesse, actual Tarragona. Si bé el jaciment és conegut des de, com a mínim, l'any 1923 (Otiña i Vergès, 2004), no fou objecte de publicacions científiques fins a la dècada dels anys 80 del segle passat, per membres de l'Institut d'Estudis Vallencs (Fabra i Burguete, 1986), els quals hi van portar a terme la primera excavació arqueològica amb metodologia moderna l'any 1983 (Fabra i Vilalta, 2016: 149). Entre l'octubre i novembre de l'any 1995 hi tingueren lloc unes excavacions arqueològiques d'urgència (Vergès, 1995) en les quals es localitzaren algunes sitges farcides de material ceràmic, així com un seguit de murs. Diferents intervencions realitzades entre el 2000 i el 2008 posaren al descobert més restes constructives i importants conjunts ceràmics (Fabra, 2016). Al desembre del 2013, investigadors de la Universitat de Barcelona i l'Institut Català d'Arqueologia Clàssica van iniciar tot un seguit de prospeccions arqueològiques a la zona. Aquests treballs han permès identificar, hipotèticament, les restes superficials trobades amb la localització del campament del general cartaginès Hannó, que fou arrasat, juntament amb l'antiga Kissa (Polibi, III, 76) o Cissis (Livi, XXI, 60), durant la intervenció militar d'Escipió. Just a la vora del poblat ibèric del Vilar, que també fou destruït violentament a finals del segle III aC, es trobaren, molt disperses, monedes cartagineses i projectils de fona, que permeten plantejar la hipòtesi que es tracti del campament cartaginès d'Hannó i que el Vilar de Valls sigui realment la Kissa/Cissis esmentada pels autors clàssics (López Vilar i Noguera, 2015; Noguera et al., 2018: 897).

La vil-la romana del Vilar, en la qual centrarem el present treball, fou descoberta arran del projecte d'urbanització «Eixample el Vilar», iniciat l'any 2000, que va motivar la realització d'una intervenció arqueològica a l'àrea de protecció arqueològica afectada per les obres, situada a tocar del poblat ibèric del Vilar. Els treballs arqueològics efectuats van permetre documentar les restes d'una villa romana que ocupa una extensió d'uns $5.000 \mathrm{~m}^{2}$. Entre el conjunt, hi destaca l'existència d'una zona termal, construïda a partir de la segona meitat del segle I dC, i una pars rustica, on s'hi establí una terrisseria que es trobava en ple funcionament en el tercer quart del segle II aC (Adserias Sans i Ramon Sariñena, 2007: 194-195); així ho demostra l'existència d'un gran abocador ceràmic format per, aproximadament, uns 17.000 fragments ceràmics i una bassa de decantació d'argiles. Aquestes restes es poden relacionar amb un conjunt de murs, construïts amb pedres irregulars lligades amb fang, que configuren una sèrie d'àmbits de treball pertanyents a l'àrea industrial (Adserias Sans i Ramon Sariñena, 2004: 9). Malauradament, no s'han pogut documentar els forns on foren elaborades les produccions ceràmiques, però sí que s'han trobat nombrosos fragments de peces que presenten deformacions i clars indicis 
de sobrecocció, la qual cosa demostra, inequívocament, que es tracta d'una terrisseria (Adserias Sans i Ramon Sariñena, 2004). Tot sembla indicar que la villa fou abandonada a inicis del segle III dC.

Cal recordar que aquesta zona fou objecte de prospeccions força intensives a finals dels anys 80 del segle xx, i els resultats publicats (Carreté et al., 1995) mostren com, en el terme municipal de Valls, van aparèixer, a part d'altres materials, dos fragments d'ansa d'àmfora Dressel 1 local amb el mateix segell, emmarcat dins cartel·la rectangular, i en alfabet iber del NE. La marca es pot llegir com N.I.O, sense un significat clar (Carreté et al., 1995: 83). Els autors ja apuntaren que es tracta de produccions de l'ager de Tarraco, de manera que possiblement es tracti d'àmfores fabricades al Vilar, o d'una altra terrisseria situada a la zona de l'actual municipi de Valls, encara no descoberta. En aquest sentit, és interessant assenyalar que a Fontscaldes, nucli urbà situat aproximadament a $6 \mathrm{~km}$ del Vilar de Valls, es coneix l'existència d'un forn ibèric que va produir diferents formes ceràmiques indígenes amb una cronologia que va des de finals del segle III aC fins a mitjans del segle II aC (Solé Folch, 1996: 114).

A part, volem destacar l'existència, en altres indrets de la Provincia Hispania Citerior, d'una sèrie de testimonis epigràfics en llengua ibèrica en produccions ceràmiques de tradició plenament romana (Pérez Suñé i Revilla, 1997). És el cas d'un exemplar de Tarraconense 1, trobat a Salduie i transcrit com E.I.KE.BI (Aguarod, 1992). El següent exemple es troba imprès sobre un fragment d'àmfora grecoitàlica del jaciment de Sant Josep (Castelló), que porta in ansa la marca DU.N.CA o CA.N.DU. Finalment, al jaciment de Torre de la Sal, també a Castelló, un fragment d'ansa d'àmfora grecoitàlica duu el segell CA.GI.R (Flors, 1994: 275-277).

\section{Les produccions de grecoitàlica i Dressel 1 a Hispania}

La producció d'imitacions d'àmfores grecoitàliques i Dressel 1 a la Hispania Citerior no disposa d'una documentació arqueològica tan abundant com altres tipologies amfòriques, ja que les terrisseries on aquestes es fabricaren són força escadusseres i pràcticament es desconeixen els centres de consum fora de la costa nord-est de la península Ibèrica. Les primeres notícies de l'existència d'aquestes imitacions locals provenen de les excavacions arqueològiques portades a terme als oppida de Burriac (Cabrera de Mar) i a Montpalau (Pineda de Mar), entre els anys 1981 i 1982 (Miró i Pujol, 1983: 40; Miró et al., 1988: 32 i 69), donant-se a conèixer altres contextos a posteriori, com el del fondejador de Vilassar de Mar (Coll i Járrega, 1986: 13-14), a la comarca del Maresme, i a Baetulo (Comas et al., 1987).

En la zona nord-est de la península Ibèrica, s'han localitzat diverses figlinae en els abocadors de les quals es documenta, encara que en una proporció molt reduïda, la imi- 
tació d'aquests contenidors destinats al transport del vi. Sense ànim de ser exhaustius, passem a esmentar els centres productors d'aquestes tipologies amforals a la zona litoral mediterrània de la Provincia Hispania Citerior. En primer lloc tenim el cas de la figlina de Ca l'Arnau - Can Pau Ferrer (Cabrera de Mar), on es documenta la manufactura d'imitacions d'àmfores grecoitàliques, encara que de forma quasi testimonial (Martínez Ferreras et al., 2005: 392-393, amb bibliografia anterior), a més d'una producció de Dressel 1B, ben representada per un exemplar complet (López Mullor i Martín Menéndez, 2008: 39, fig. 3). A Can Portell i Can Balençó (Argentona) també es té constància de la fabricació de Dressel 1A i 1B, una de les quals amb marca Q.FABI in labro (CODEX, 1992; Revilla, 1995: 247), encara que també es tracta d'una producció força minoritària (García Roselló i Gurri Costa, 1997: 413). A la Laietània interior coneixem el cas de la Salut (Sabadell), on es localitzaren alguns fragments d'àmfora de tipologia Dressel 1B, una de les quals presentant la marca M.COR o M.COS in labro (Casas, 1987; Carreras, 2019: 141-142, n.19.al). A Can Vendrell (Santa Eulàlia de Ronçana) es recuperà un fragment de vora de Dressel 1 amb marca Q.T.E in labro i un grafit ante cocturam amb caràcters ibers «ke» $\mathrm{O}$ "ko» (Pera, 1994; Olesti, 1998: 414).

A la Cossetània oriental, trobem els casos de les figlinae de Darró, a Vilanova i la Geltrú (López Mullor, 2009: 84); Tomoví, a Albinyana del Penedès (Martín Menéndez i Prevosti, 2003), i la vil·la del Vilarenc, a Calafell (Revilla, 2010). Novament, en aquests jaciments més meridionals, es tracta també de produccions molt limitades.

Grosso modo, els centres de producció mencionats, localitzats a la Provincia Hispania Citerior, no inicien la seva activitat amb total seguretat fins a inicis del segle a aC (Berni i Miró, 2013: 64). Per altra banda, com podem comprovar, el nombre de fragments pertanyents a Dressel 1 de la Hispania Citerior recuperats en aquestes figlinae és absolutament minoritari si el comparem amb el volum de material que mostra l'abocador del Vilar de Valls (taula 1).

Pel que fa a la Provincia Hispania Ulterior, comentarem succintament que també s'hi han documentat imitacions del tipus grecoitàlica a l'àrea de la badia de Cadis i l'estret de Gibraltar, encara que en una cronologia força anterior. Destaca especialment el cas del jaciment de Torre Alta (San Fernando), on es produïren, a partir del segle III aC, les imitacions de les tipologies Lyding Will C-D-E (Sáez Romero i Díaz Rodríguez, 2007, amb bibliografia anterior). Pel que fa a les imitacions de Dressel 1A, tenim els casos de les ter-

Taula 1. Categories ceràmiques locals del Vilar de Valls (dades extretes de la memòria d'excavació inèdita)

\begin{tabular}{lc}
\hline Tipus & Nre. de fragments \\
\hline Àmfora & 7.101 \\
Ceràmica comuna oxidada & 7.187 \\
Ceràmica comuna reduïda & 277 \\
Parets fines & 2.538 \\
Pondera & 42 \\
Altres (rebuig ceràmic, fragment de forn) & 282 \\
\hline
\end{tabular}


risseries de San Fernando i Pery Junquera (San Fernando), que inicien la seva activitat entorn del 140-130 aC (Bustamante i Martín Arroyo, 2004: 445), El Rinconcillo (Algesires) (Fernández Cacho, 1995: 205) i a Carteia, Algesires (Bernal et al., 2011). També es coneix una producció a la vall del Guadalquivir que arrenca a finals del segle II aC, encara que a dia d'avui no se n'han trobat gaires exemplars, procedents del jaciment de La Loba (Fuente Obejuna) (Benquet i Olmer, 2002), Hispalis (García Vargas et al., 2011) i Scallabis (Almeida, 2008: 60-67), i d'altres que, com a principal peculiaritat, fan dos terços de la mida original de les Dressel 1 itàliques.

\section{Les produccions amforals del Vilar}

L'anàlisi de les produccions ceràmiques del Vilar s'ha realitzat mitjançant l'estudi dels materials pertanyents a la UE 4018, inèdits, exceptuant alguns dibuixos publicats de forma succinta (López Mullor i Martín Menéndez, 2008: 35, fig. 1). Aquesta unitat estratigràfica comprèn un total de 17.377 fragments ceràmics, majoritàriament d'àmfores i ceràmica comuna oxidada (vegeu taula 1), entre d'altres. Les formes més representades dins d'aquest darrer grup són imitacions de pàteres de vernís negre del tipus Lamb. 27 i Lamb. 36, i també formes ibèriques, com contenidors de llavi de perfil zoomorf i els càlats. Dins la ceràmica comuna reduïda, destaquen les gerres, algunes de les quals bicòniques de tradició indígena. Pel que fa a la ceràmica de parets fines, es tracta d'imitacions de cubilets de les formes Mayet I i Mayet II. Finalment, també cal fer esment de la presència, encara que de forma molt més minoritària, d'una producció de pondera i morters. Totes aquestes produccions s'han considerat com a manufacturades al Vilar, per la composició de visu de les pastes ceràmiques (Adserias Sans i Ramon Sariñena, 2007: 194). Si bé els tipus Lamb. 27 i 36, així com Mayet I-II, presenten un hiatus cronològic força ampli (López Mullor, 2013: 154-156), gràcies a la presència d'àmfores grecoitàliques i Dressel 1A de transició, podem datar la formació d'aquest abocador en algun moment del tercer quart del segle II aC, ja que Tchernia (1983) situà la data de pas entre aquestes produccions amforals cap al 140-130 aC.

Com es pot comprovar al gràfic 1 , les àmfores, juntament amb la ceràmica comuna oxidada, són la categoria ceràmica més abundant a l'abocador del Vilar, ja que constitueixen un 40,75 \% del total. La producció de contenidors destinats a la comercialització del vi està representada per imitacions de models itàlics, dels tipus grecoitàlica tardana o de transició (formes Lyding Will E) i Dressel 1A, a més d'algunes vores d'àmfora de tipologia que no hem pogut classificar (gràfic 2). El material es troba molt fragmentat i no s'ha realitzat cap tipus de restauració per tal d'unir-ne els fragments, per la qual cosa resulta molt complicat restituir el perfil complet de les produccions; si bé, gràcies a les tècniques de documentació gràfica en tres dimensions, hem pogut plantejar la restitució completa de les dues principals formes amforals. 


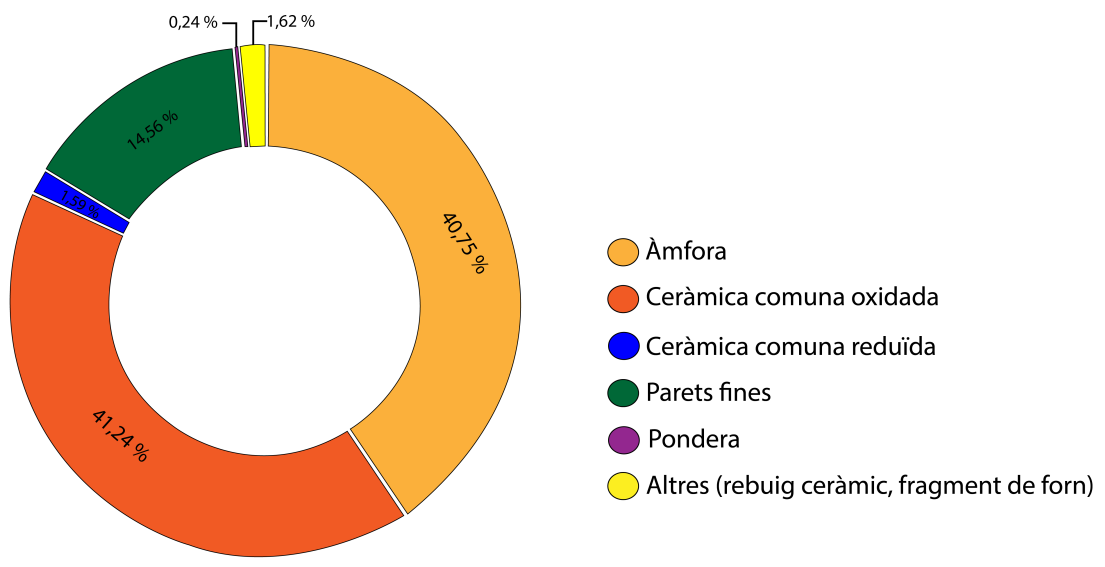

Gràfic 1. Percentatge de representativitat de les categories ceràmiques del Vilar.

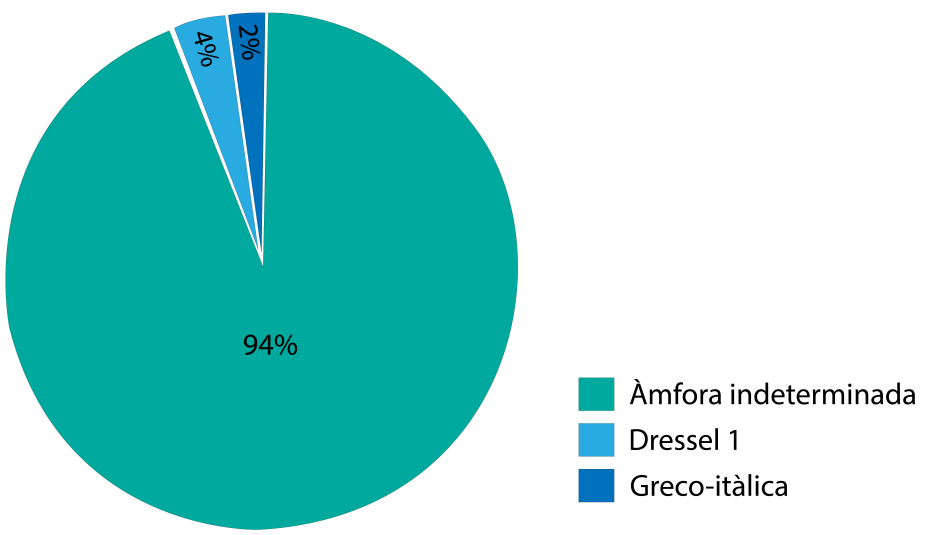

Gràfic 2. Percentatge de representativitat dels fragments d'àmfora de producció local.

\subsection{Les àmfores grecoitàliques tardanes}

Els fragments que hem pogut identificar com a pertanyents a la tipologia grecoitàlica Lyding Will E suposen un 2\%, dins del 6\% de fragments atribuibles a una forma d'àmfora concreta (taula 2). Cal recalcar que es tracta de produccions d'àmfora grecoitàlica tardana, en transició a la forma Dressel 1A, amb varietat en el perfil dels llavis analitzats, ja que alguns són més exvasats i desenvolupats, com els de les formes clàssiques de grecoitàlica (amb forma de «bec d'ànec»), i d'altres força semblants a les produccions de Dressel 1A, essent en ocasions difícils de diferenciar. Els llavis són força baixos (fig. 1.1 i 1.3), de tendència triangular, amb una projecció en aresta cap a l'exterior. El diàmetre mitjà 
Taula 2. Classificació dels fragments d'àmfora del Vilar

\begin{tabular}{lc}
\hline Tipologia amforal & Nre. de fragments \\
\hline Àmfora indeterminada (Dressel 1A o grecoitàlica) & 6.702 \\
Vores de Dressel 1A & 271 \\
Vores de grecoitàlica & 128 \\
\hline
\end{tabular}

de les vores és d'uns 12-15 cm. Les anses sí que mostren la morfologia clàssica d'aquestes produccions, amb el perfil corbat tan característic i l'arrencament a la zona d'unió del coll amb la carena de l'espatlla, on en nombroses ocasions hi apareixen digitacions, intentant imitar a la perfecció els prototips itàlics. La secció d'aquestes produccions també és la típica, de forma el·líptica i oval. Els colls són allargats i robustos, de tendència cilíndrica i amb el punt de diàmetre mínim a mitja altura. Cal destacar que les produccions del Vilar presenten colls més estrets que els prototips produïts al Mediterrani central, assemblant-se més a les produccions bètiques. Els pivots són força allargats i de mida mitjana i, com a principal tret característic, alguns estan rematats amb una motllura en forma de projecció cònica sobresortint. Hem dut a terme una reconstrucció del perfil general d'aquestes àmfores (fig. 1.3) i, com es pot comprovar, presenten una morfologia fusiforme i estilitzada, amb una longitud total calculada d'uns $85-90 \mathrm{~cm}$.

\subsection{Les àmfores Dressel $1 \mathrm{~A}$ arcaiques}

Les produccions locals de Dressel 1A, formades per un 4\% dins del $6 \%$ del total de fragments amb forma (taula 2), presenten una morfologia general ben diferenciada de les documentades a altres terrisseries de la Provincia Hispania Citerior, com per exemple a Ca l'Arnau i Can Pau Ferrer, a Cabrera de Mar (García et al., 2000: 41; Martín Menéndez, 2004). Les produccions del Vilar presenten trets tipològics més arcaics, característics del moment de transició de les formes grecoitàliques cap a les Dressel 1, per la qual cosa pensem que la figlina del Vilar va iniciar la producció d'aquests contenidors força decennis abans que altres terrisseries del NE peninsular. Els fragments analitzats mostren certa variabilitat en la secció de les vores (fig. 1.2), encara que, a trets generals, són altes, de secció triangular i, com a característica més particular i definitòria, en la majoria d'ocasions presenten una o dues estries ben marcades a mitja altura. A la part interior de la vora, a la zona inferior de l'arrencament del llavi, a cops hi ha un petit esgraó. Els colls són cilíndrics i més robustos i curts que els de les Dressel 1 itàliques i les produccions de la zona del Maresme i són gairebé idèntics als que presenten les formes de grecoitàlica locals, així com les anses, de secció el-líptica, i amb la corba en forma de "S». Aquestes dades apunten que la formació de l'estrat es va produir en el moment de transició entre ambdues formes. Com es pot comprovar a la restitució de la forma completa efectuada (fig. 1.4), la morfologia general del cos és fusiforme, rematat per pivots llargs i massissos, que en ocasions presenten una projecció sobresortint de forma cònica, que pot ser també 

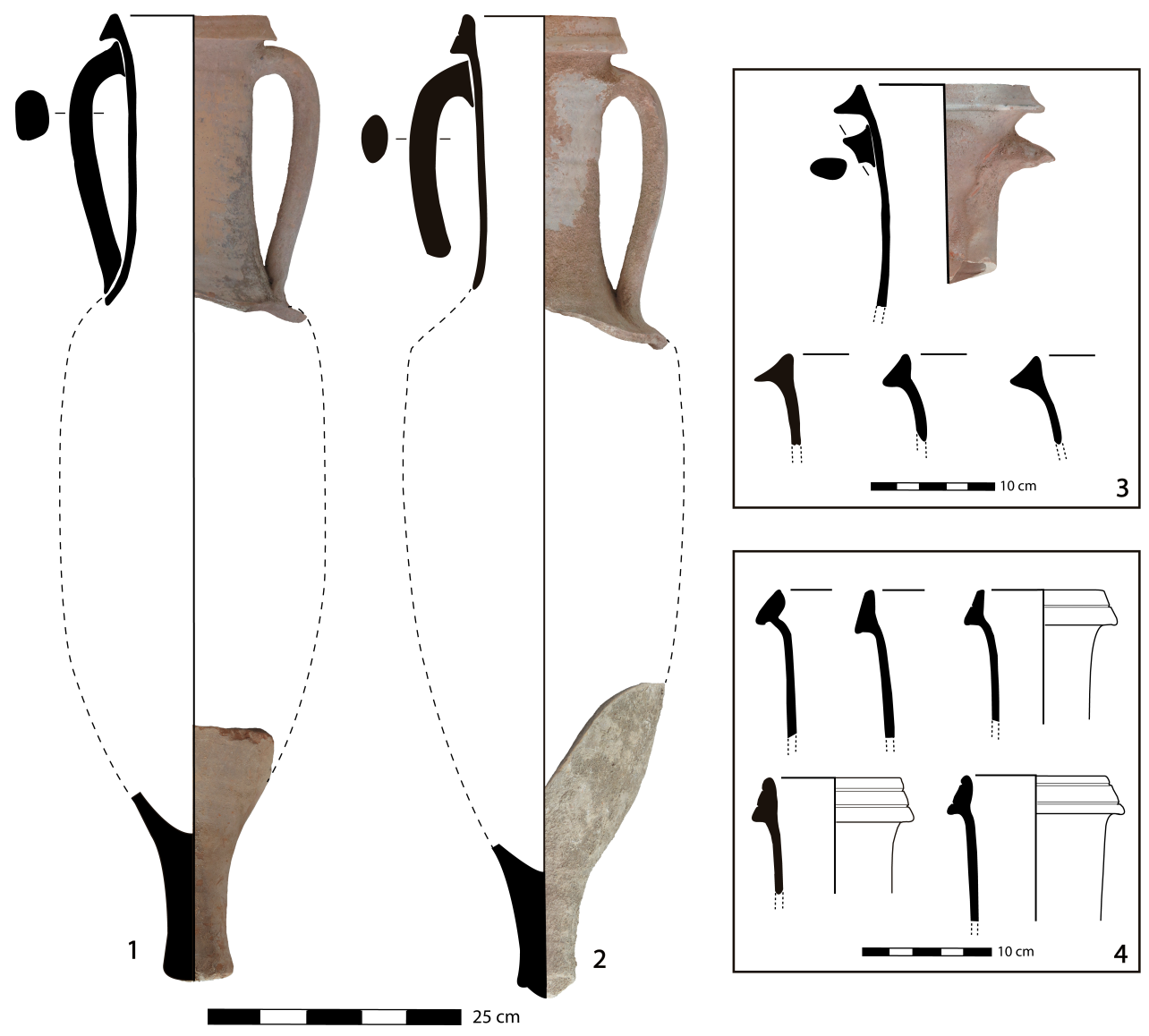

Figura 1. 1 i 2: Restitució hipotètica dels perfils generals de les àmfores grecoitàlica i Dressel 1A del Vilar de Valls. 3: Vores de grecoitàlica. 4: Vores de Dressel 1A. Ortofotografies i dibuixos arqueològics de l'autor.

circular, a la part inferior (fig. 3.2). La longitud màxima estimada oscillla entre els 90 i 100 $\mathrm{cm}$, amb un diàmetre extern de vora d'entre 12 i $15 \mathrm{~cm}$. Cal destacar que, a grans trets, són més semblants morfològicament a les produccions bètiques que no pas a les laietanes més septentrionals.

\subsection{Les àmfores ovoides de producció local}

Menció a part mereixen aquestes produccions, de mides molt inferiors a les variants estàndard i que, en principi, es podrien identificar com a versions parvae. Al mateix temps, aquesta atribució presenta certes dificultats, ja que l'únic tret que tenen en comú amb les 

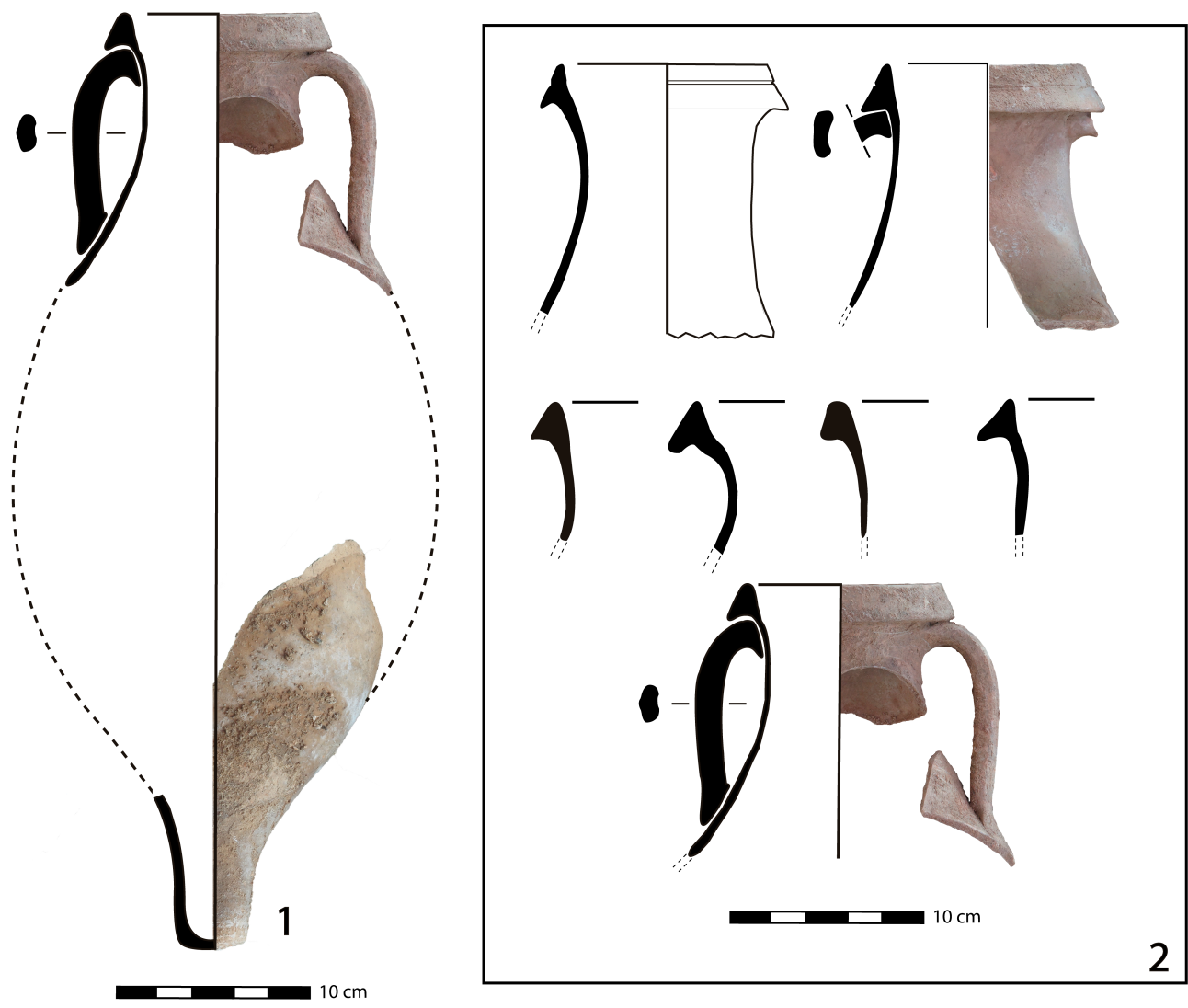

Figura 2. Restitució hipotètica del perfil general d'àmfora ovoide de producció local. 2: Exemplars de vores i terços superiors d'àmfores ovoides amb vores idèntiques a les de les Dressel $1 \mathrm{~A}$ i grecoitàlica. Ortofotografies i dibuixos arqueològics de l'autor.

variants estàndard de Dressel $1 \mathrm{~A}$ i grecoitàlica són les vores, així que molt possiblement ha de tractar-se de produccions diferenciades. Presenten unes dimensions reduïdes, de tan sols 45-50 cm d'alçada, i, per la restitució de la forma completa que hem dut a terme (fig. 2.1), es pot veure que es caracteritzen per una morfologia general ovoide. El perfil de les vores és triangular, amb una alçada màxima que oscillla entre els 1,6 i els 2,2 cm, i en el cas de les que estan inspirades en les Dressel 1A locals, també mostren una estria o acanalat a la cara externa i l'esgraó a la part interna. El diàmetre màxim de la vora és d'11,3 cm i el diàmetre intern de 7,8 cm, és a dir, amb boques molt amples amb relació a la longitud total de l'àmfora. El coll és ample, amb el diàmetre màxim a la zona de l'arrencament inferior de les anses, i, en proporció, és més curt que en les produccions estàndards del Vilar. Les anses també són curtes i corbades, de secció el-líptica i apaïsada, i arrenquen des de la carena d'unió de la campana amb el cos fins a l'arrencament del llavi, 

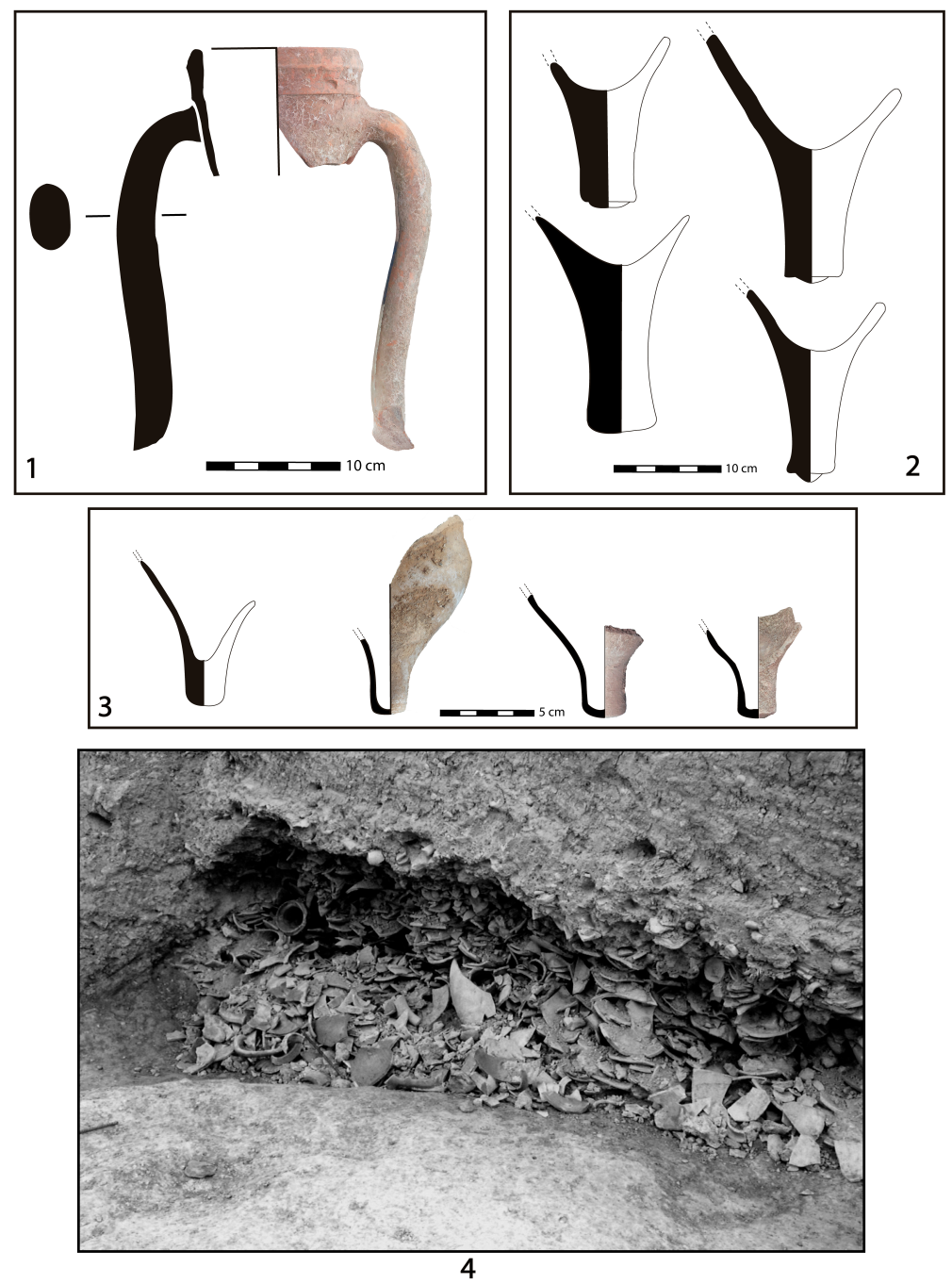

Figura 3. Fragment de part superior d'àmfora El Vilar I. 2: Diferents tipus de pivot documentats de les formes «estàndard». 3: Pivots d'àmfores ovoides de producció local. 4: Imatge del nivell d'abocador del Vilar de Valls durant la seva excavació (foto: Samuel Burguete). Ortofotografies i dibuixos arqueològics de l'autor.

on queden enganxades. Els pivots són curts, de tan sols uns $3 \mathrm{~cm}$, i buits, a diferència de les produccions estàndard, en què són massissos. Com a element a destacar, el gruix de les parets dels individus recuperats és de tan sols $0,4 \mathrm{~cm}$. La seva morfologia general recorda vagament formes més antigues de grecoitàlica, com per exemple les variants D (Lyding Will, 1982: làm. 85.d). 
Val a dir que el perfil ovoide d'aquestes produccions, juntament amb les boques i colls amples i en contacte amb l'arrencament superior de les anses, així com els pivots, allargats i buits, també plantegen una hipòtesi molt suggeridora. Tal volta es puguin identificar, de forma cauta, amb envasos destinats a contenir salaons, salses de peix o derivats, els quals serien els primers d'aquest tipus fabricats a Hispania, i els ancestres de les àmfores ovoides gaditanes, d'època tardorepublicana.

Cal recalcar que en època alt-imperial és té constància de l'elaboració de contenidors destinats a l'envasament de salaons o salses de peix, del tipus Dressel 7-11, a diverses terrisseries de l'ager Tarraconensis, com seria el cas dels Antigons, la Buada (Járrega i Prevosti, 2011: 463-464) i, possiblement, a Mas de Gomandí (Járrega i Prevosti, 2011 : 459-461).

\subsection{Un possible nou perfil inèdit produït a la figlina del Vilar}

Es tracta d'un perfil de vora inèdit, completament diferent de la resta de produccions amforals de la terrisseria (fig. 3.1), amb llavis rectes de 3,20 cm d'alçada màxima i un lleuger engrossiment a la part superior interna d'aquests, una motllura convexa a mitja altura i un petit esgraó a l'inici d'aquesta, en el punt on s'uneix amb el coll. El diàmetre màxim de la vora és de $12,1 \mathrm{~cm}$. Les anses presenten una morfologia molt semblant a les grecoitàliques, de secció el-líptica i descrivint una suau corba entre els dos punts de connexió amb la part superior i inferior del coll. Ja que es tracta d'una forma absolutament minoritària dins el repertori tipològic amforal d'aquesta terrisseria, no hi farem més èmfasi, podent ser el resultat, senzillament, d'un error de modelatge.

\subsection{Anàlisi macroscòpica de les pastes ceràmiques}

Vam seleccionar alguns fragments de les produccions locals del Vilar de Valls per analitzar-los amb lupa binocular a 20 i 40 augments. Com es pot apreciar (fig. 4), les pastes ceràmiques són força depurades, amb desgreixant relativament poc abundant, de morfologia majoritàriament subarrodonida, corresponent a la fracció de sorra fina i mitjanament grollera $(\leq 0,5 \mathrm{~mm})$, format majoritàriament per quars, roques calcàries blanquinoses, partícules de color obscur, i partícules de mica quasi imperceptibles a ull nu. La pasta és dura, rugosa al tacte i resistent a la fractura. El color varia entre l'ataronjat i el marró-beix. Alguns exemplars presenten una pàtina de color groc pàl·lid a la superfície externa.

Alguns exemplars d'àmfores grecoitàliques presenten la típica pasta de "sandvitx» que caracteritza les produccions ibèriques, amb l'exterior de color entre groc intens i ataronjat i el nucli rosat. Això podria demostrar la participació de treballadors i artesans ibèrics en aquesta terrisseria, a falta d'una justificació empírica basada en l'epigrafia. 


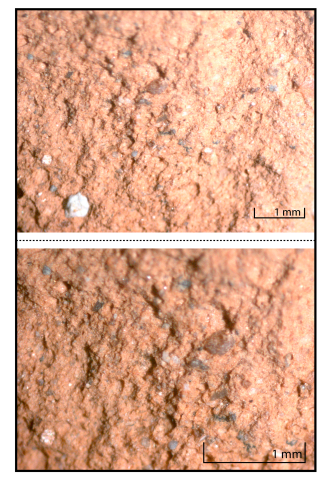

1

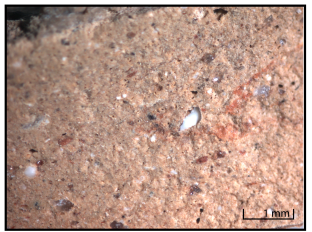

3

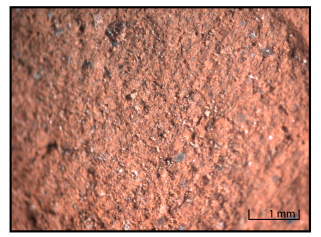

5

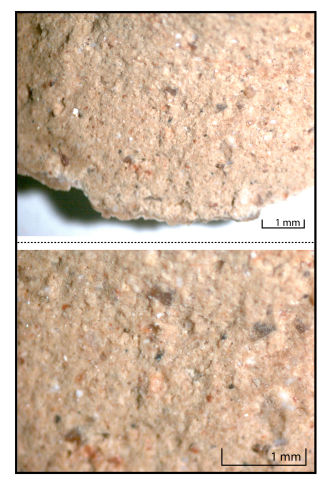

2

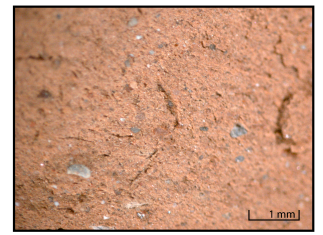

4

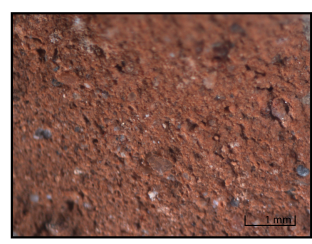

6

Figura 4. Mostra de grecoitàlica a 20 i 40 augments. 2: Mostra I d'àmfora ovoide a 20 i 40 augments. 3: Mostra II d'àmfora ovoide a 20 augments. 4: Mostra I de Dressel 1A a 20 augments. 5: Mostra II de Dressel $1 \mathrm{~A}$ a 20 augments. 6: Mostra III de Dressel $1 \mathrm{~A}$ a 20 augments.

\section{Reflexions finals i apunts per a futures recerques}

L'estudi de les categories ceràmiques, i més específicament dels tipus amforals localitzats a la UE 4018 de l'abocador del Vilar de Valls, permet extreure algunes conclusions preliminars sobre el període de funcionament i les produccions amforals de la figlina, que la converteixen en un unicum dins la Provincia Hispania Citerior.

Com ja van indicar M. Adserias i E. Ramon (2004), les formes ceràmiques produïdes en aquesta terrisseria ens mostren que ja es trobava en plena activitat en el darrer terç del segle II aC, la qual cosa contradiu el pensament generalitzat que les produccions amforals al hinterland de Tarraco serien d'època augustal avançada o més tardana (Gebellí, 2007: 146 i 155). Dissortadament, no disposem de més indicis al respecte que ens permetin explicar aquesta falta de continuïtat en les produccions amforals en el territorium de Tarraco, ja que a l'abocador del Vilar no apareixen representades les tipologies típiques del darrer terç del 
segle $\mathrm{a} \mathrm{aC}$ i dels primers decennis del $\mathrm{I} \mathrm{dC}$, com serien les àmfores Pascual 1 , les Oberaden 74 i les Dressel 2-4. Per aquest motiu, sembla tractar-se d'una terrisseria que respon a unes necessitats determinades d'un període concret. Esperem que futures excavacions arqueològiques ens ajudin a minimitzar aquest buit de coneixement, que converteix la terrisseria del Vilar de Valls en quelcom aïllat, i sense solució de continuïtat.

Prenent com a base l'anàlisi dels materials ceràmics, tant de les àmfores com de la ceràmica fina, podem concloure que possiblement no es tracti únicament de la figlina més antiga documentada a la zona de l'actual Tarragona, sinó que ens podríem trobar davant de, si no la primera, una de les més antigues terrisseries en què es fabricaven imitacions d'àmfores itàliques de tota la Provincia Hispania Citerior. Basem les nostres afirmacions en l'elevat volum de fragments de rebuig de la forma grecoitàlica, en comparació amb altres figlinae en les quals també s'imiten aquestes produccions, com és el cas de Ca l'Arnau Can Pau Ferrer (Cabrera de Mar), on l'aparició d'aquesta forma és més escassa i, segons els autors (Olesti, 1997: 431), pertany al primer-segon quart del segle I aC. També cal fer referència a la morfologia de les Dressel $1 \mathrm{~A}$ del Vilar, amb un perfil general que mostra característiques arcaïtzants que hem de situar en un moment de transició entre la forma grecoitàlica tardana (Lyding Will E) i la Dressel 1A, com així ho demostra la forma del coll i de les anses, fortament influenciades per la forma que és substituïda. Com ja hem avançat anteriorment, aquesta transició fou datada cap al 140-130 aC per alguns autors (Tchernia, 1983; Lyding Will, 1982). Seguint aquesta línia, podem afirmar que aquestes imitacions d'àmfores itàliques són més semblants a les formes documentades a la Provincia Hispania Ulterior, ben datades entorn de mitjans-finals del segle II aC (Bernal et al., 2007: 258, fig. 25), que no pas a les documentades a la costa nord-est de la península Ibèrica, més modernes des del punt de vista tipològic. També s'ha de fer especial esment de les marques en alfabet ibèric recuperades durant les prospeccions dutes a terme en els anys 80 del segle passat a l'Alt Camp (Carreté et al., 1995: 83), que són novament testimonis esclaridors en aquest sentit, ja que els segells recuperats sobre àmfores Dressel 1 produïdes a l'actual zona del Maresme ja mostren caràcters en alfabet llatí (Carreras, 2019: 173-174, n.54.a3 i 185, n.86.al, amb bibliografia anterior). En definitiva, tot i que l'àrea laietana és la que presenta una major concentració de forns destinats a la fabricació d'aquestes primeres imitacions d'àmfores itàliques, tots els indicis apunten que sorgirien en un moment posterior; cosa que no ens hauria d'estranyar, ja que Tarraco fou el primer cap de pont dins la península Ibèrica, en forma de campament d'hivern fundat per Gneu Corneli Escipió l'any 218 aC (Ruiz de Arbulo, 2015, amb bibliografia anterior), si bé existeixen algunes interessants i suggeridores revisions en aquest aspecte, que situarien la implantació urbanística ex novo de la ciutat en el tercer quart del segle II aC per part de Publi Corneli Escipió Emilià (Járrega, 2004). Aquest fet podria explicar la ràpida implantació del model d'explotació econòmica itàlic en aquesta àrea, com és el cas de la villa del Vilar, que ja està en ple funcionament en el darrer terç del segle II aC. Tot junt, podria servir de referència per mesurar el procés inicial de la romanització a la costa mediterrània nord-oriental d'Hispania, amb un origen més antic en el territori de Tarraco que en el laietà. 
Ja que desconeixem si les marques documentades in ansae, en alfabet ibèric, a jaciments de l'Alt Camp procedeixen dels forns del Vilar, no podem afirmar amb total seguretat que les produccions de Valls estiguin controlades per indígenes, com alguns autors han posat de manifest (Járrega, 1998: 430). El que sí que podem afirmar és que es tracta d'una producció de vi amb una clara finalitat exportadora a través del port de Tarraco, encara que no podem dilucidar, amb les dades de què disposem a dia d'avui, el paper que jugaren les gents autòctones dins aquest procés. El fet d'haver documentat algunes pastes ceràmiques amb una cocció tipus "sandvitx", tan definidora de les produccions amforals ibèriques, tan sols ens demostra que els figuli podrien haver estat indígenes, ja dins un sistema econòmic romà provincial.

De la mateixa manera, tampoc podem discernir si la decisió d'imitar les formes grecoitàlica i Dressel 1A en un moment tan primerenc respon a la voluntat de copiar un disseny exitós des del punt de vista comercial, encara que no tecnològic, com s'ha posat de manifest (Vila Socias, 2010: 169), o si es tracta d'inversors itàlics que comencen a explotar el territorium de Tarraco per enriquir-se, i van escollir aquestes tipologies perquè són les ja conegudes de la península Itàlica i les que es troben en circulació dins l'àmbit mediterrani, en detriment de les àmfores ibèriques, tal vegada relacionades de forma pejorativa amb la vitivinicultura indígena.

Pel que fa a les àmfores ovoides de producció local i petites dimensions, dissortadament, amb les dades actuals, no podem oferir cap hipòtesi concloent. Tal volta podrien envasar vins de major qualitat, com ja hem apuntat en altres ocasions (Colom Mendoza i Járrega Domínguez, en premsa), o derivats i preparats especials del vi (mulsum, defrutum, sapa, etcètera), fet que justificaria la dràstica reducció en el volum de les àmfores, fent-les rendibles malgrat l'esforç de miniaturitzar-les. També, com ja hem indicat anteriorment, podria tractar-se d'envasos destinats a contenir salaons o salses de peix, encara que es tracta d'una hipòtesi força feble, ja que ens manquen paral·lels contemporanis a Hispania, per la qual cosa cal aprofundir més en aquesta qüestió de cara a un futur.

Òbviament, la producció amforal del Vilar de Valls està íntimament lligada a la voluntat comercialitzadora del producte, ja que es tracta de contenidors ceràmics que només tenen sentit si se'n preveu una exportació per via marítima. No podem oferir més dades en aquest aspecte, ja que no coneixem en absolut l'abast i l'acceptació dels vins produïts a l'ager de Tarraco en aquest moment tan primerenc. A aquest fet hi hem de sumar la total desconeixença, fins ara, de l'aspecte de les pastes ceràmiques de les àmfores fabricades al Vilar, per la qual cosa probablement poden haver estat classificades en els centres importadors com a àmfores itàliques o indeterminades. A tall d'exemple, en l'estudi de les importacions ceràmiques documentades al territorium de Tarraco, dins del marc del Projecte Ager Tarraconensis (PAT), el $95 \%$ dels exemplars del grup format per les àmfores de tipologia grecoitàlica i Dressel 1 tenen una procedència desconeguda (Járrega i Abela, 2011: 146-147). A més, sembla que l'única particularitat morfològica introduïda pels terrissaires a les Dressel 1A del Vilar és la presència de les estries o línies acanalades a la vora, cosa que complica encara més la seva diferenciació amb altres pro- 
duccions. Si seguim amb aquesta línia, podem observar com, per exemple, en contextos del darrer terç del segle II aC, a Tarraco hi apareix aquest perfil, de forma molt escassa, així com en el segon quart del segle i aC (Díaz García, 2016: 168, fig. 3.5 i 174, fig. 6.4), encara que atribuït a importacions itàliques. Pensem que, amb les noves dades que aquí aportem, seria interessant dur a terme una nova revisió dels contenidors itàlics d'aquests tipus documentats, tant a Tarraco com en el seu territorium.

També tenim, a nivell d'hipòtesi, el cas del derelicte Grand Bassin B, naufragat a Gruissan, a la zona portuària de Narbo. El seu carregament estava format per àmfores Dressel lA, amb una pasta ceràmica de color marró-vermellós i rosada, molt ben depurada i cuita, amb desgreixant format per partícules de quars i punts foscos brillants (Solier et al., 1981: 59). Acompanyant les àmfores, es documentaren diverses formes de Campaniana A (formes Lamb. 27, 28, 31/33, 36 i 42B), Campaniana B (formes Lamb. 1, 2, 4 i 5/7) i ceràmica grisa i comuna. Volem destacar aquest derelicte en concret per la presència d'una vora de Dressel lA acanalada (Solier et al., 1981: 60, fig. 20.9) i un pivot amb grafit post cocturam en alfabet ibèric en signari nord-oriental, i al mobiliari de la tripulació, entre el qual sobresurt un gran plat de bronze amb una inscripció ibèrica i, finalment, quatre monedes de bronze encunyades a Cesse amb una cronologia del primer quart del segle I aC (Solier et al., 1981: 84-85). Per tant, podem establir, a nivell hipotètic, que aquest navili cobriria la ruta comercial entre Roma i Tarraco, o possiblement es tractaria d'una embarcació dedicada al comerç de redistribució des de Tarraco fins a Narbo, o viceversa, on es podrien haver descarregat algunes d'aquestes àmfores Dressel 1 A produïdes a la figlina del Vilar, destinades als contingents militars romans que operaren al sud de la Gàl-lia durant aquest període. Malauradament, tan sols disposem d'aquests exemples, que no deixen de ser merament hipotètics.

Pensem que el redescobriment i estudi dels materials d'aquest abocador suposa una baula més en el coneixement de les produccions amforals de l'àrea d'influència de Tarraco i permet aportar una mica més de llum a la suposada manca d'informació sobre la fabricació de contenidors destinats a l'exportació de vi en aquesta zona, des de finals del segle II i principis del I aC.

\section{Agraïments}

Volem agrair especialment a Ester Fabra, de l'Institut d'Estudis Vallencs, la seva ajuda en la localització dels materials, així com totes les facilitats ofertes a l'hora de realitzar el nostre estudi. També volem donar les gràcies a Samuel Burguete per haver-nos facilitat fotografies de l'abocador del Vilar. Finalment, volem agrair les correccions i suggeriments dels revisors/es, que han permès ampliar i millorar aquesta publicació. Aquest treball s'ha portat a terme gràcies al finançament del contracte predoctoral FPI 2016, finançat pel MINECO-FEDER en el marc del projecte $\mathrm{R}+\mathrm{D}+\mathrm{I}$ «Amphorae ex Hispania: sistematización y accesibilidad en red de los centros de producción». 


\section{Bibliografía}

ADSERIAS SANS, M. i RAMON SARIÑENA, E., 2004, La vil-la romana del Vilar (Valls, Alt Camp), Quaderns de Vilaniu 45, 5-18.

ADSERIAS SANS, M. i RAMON SARIÑENA, E., 2007, La vil-la romana del Vilar (Valls, Alt Camp), a J. A. REMOLÀ (coord.) El territori de Tarraco: vil-les romanes del Camp de Tarragona, 191-204.

ADSERIAS SANS, M. i RAMON SARIÑENA, E., 2008, La vil-la romana del Vilar, a J. M. VERGÈS BOSCH i J. LÓPEZ VILAR (coords.), Valls i la seva història. Prehistòria i història antiga, Vol. 2, Institut d'Estudis Vallencs, 369-376.

AGUAROD, M. C., 1992, Un ánfora Tarraconense 1 / Layetana 1 con sello ibérico procedente de Salduie, Boletín del Museo de Zaragoza 11, 109-116.

ALMEIDA, R., 2008, Las ánforas del Guadalquivir en Scallabis (Santarém, Portugal). Una aportación al conocimiento de los tipos minoritarios, Instrumenta 28, Barcelona.

BENQUET, L. i OLMER, F., 2002, Les amphores, a J. M. BLÁZQUEZ MARTÍNEZ, C. DOMERGUE i P. SILLIÈRES (eds.), La Loba (Fuenteobejuna, province de Cordoue, Espagne). La mine et le village minier antiques, 295-331.

BERNAL, D., ROLDÁN, L., BLÁNQUEZ PÉREZ, J. i SÁEZ ROMERO, A., 2011, De la producción anfórica de Carteia en época republicana. Primeras evidencias, a J. ABELLÁN PÉREZ i V. CASTAÑEDA FERNÁNDEZ (coords.), Homenaje al professor Antonio Caro Bellido, Vol. 2, 63-80.

BERNAL, D., ARÉVALO, A., SÁEZ, A.M., 2007, Nuevas evidencias de la ocupación en época republicana (ss. II-I a.C.), a D. BERNAL i

A. ARÉVALO (eds.) Las cetariae de Baelo Claudia. Avances de las investigaciones en el barrio industrial (2000-2004), 239-355.

BERNI, P. i MIRÓ, J., 2013, Dinámica socioeconómica en la Tarraconense oriental a finales de la República y comienzos del Imperio. El comercio del vino a través de la epigrafía anfórica, a J. LÓPEZ VILAR (ed.), Tarraco Biennal. Actes del ler Congrés Internacional d'Arqueologia i Món Antic. Govern i societat a la Hispània romana. Novetats epigràfiques. Homenatge a Géza Alföldy, 63-83.

BUSTAMANTE, M. i MARTÍN ARROYO, D., 2004, La producción de ánforas greco-itálicas de imitación y su evolución en la bahía gaditana durante el siglo ir a.C: los contextos de la Avenida Pery Junquera en San Fernando (Cádiz), a Actas del Congreso Internacional Figlinae Baeticae. Talleres alfareros y producciones cerámicas en la Bética romana (ss. II a.C.-VII d.C.). BAR International Series 1266, 441-446. CARRERAS, C., 2019, Catàleg de marques d'àmfora, tègula, dolia i signacula del Vallès Occidental i Oriental, a C. CARRERAS, J. FOLCH i J. GUITART (eds.), Laietània interior: marques i terrisseries d'àmfores al Vallès Occidental i Oriental, 117-196.

CARRETÉ, J. M., KEAY, S. i MILLETT, M., 1995, A roman provincial capital and its hinterland. The survey of the territory of Tarragona, Spain, 1985-1990, Journal of Roman Archaeology Supplementary Series 15, Ann Arbor.

CASAS, M. T., 1987, Estudi preliminar: les àmfores de la vil-la de la Salut (Sabadell), Arraona. Revista d'Història 1, 15-26.

CODEX, S.C.C.L., 1992, Excavació a l'autopista A19, variant de Mataró. Tres exemples del poblament del Maresme: de l'ibèric ple a la romanització, Laietania 7, 167-171.

COLL, R. i JÁRREGA, R., 1986, Troballes submarines a Vilassar de Mar. Estudi del material amfòric, Les Nostres Arrels 10.

COLOM MENDOZA, E. i JÁRREGA DOMÍNGUEZ, R., en premsa, A phase of the wine trade process on the east coast of Hispania Citerior: the production of parvae amphoras, 19th International Congress of Classical Archaeology (Cologne/Bonn, 22-26 de maig de 2018), Bonn i Colònia.

COMAS, M., MARTÍN MENÉNDEZ, A., MATAMOROS, D. i MIRÓ, J., 1987, Un tipus d'àmfora Dressel 1 de producció laietana, Jornades Internacionals d'Arqueologia Romana: De 
les estructures indígenes a l'organització provincial romana de la Hispània Citerior (Granollers, 1987), 372-378.

DÍAZ GARCÍA, M., 2016, Las ánforas de Tarraco de los siglos II y i a. C., a R. JÁRREGA i P. BERNI (eds.), Amphorae ex Hispania: paisajes de producción y consumo, Monografías Ex Officina Hispana 3, 163-183.

FABRA, M. E., 2016, El jaciment ibèric del Vilar. Ruta històrica, Institut d'Estudis Vallencs.

FABRA, M. E. i BURGUETE, S., 1986, Introducció a l'estudi del jaciment ibèric de "El Vilar», Quaderns de Vilaniu 9, 55-78.

FABRA, M. E. i VILALTA, E., 2016, Els materials arqueològics de la sitja 4 del jaciment ibèric del Vilar (Valls, Alt Camp) dipositats al Museu de Valls, Revista d'Arqueologia de Ponent 26, 147-177.

FERNÁNDEZ CACHO, S., 1995, Las industrias derivadas de la pesca en la provincia romana de la Bética: la alfarería de El Rinconcillo (Algeciras, Cádiz), SPAL 4, 173-214.

FLORS, E., 1994, Nova estampilla ibèrica sobre àmfora grecoitàlica, Quaderns de Prehistòria $i$ Arqueologia de Castelló 16, 273-279.

GARCÍA, J., MARTÍN MENÉNDEZ, A. i CELA, X., 2000, Nuevas aportaciones sobre la romanización en el territorio de Iluro (Hispania Tarraconensis), Empúries 52, 29-54.

GARCÍA VARGAS, E., ALMEIDA, R. i GONZÁLEZ CESTEROS, H., 2011, Los tipos anfóricos del Guadalquivir en el marco de los envases hispanos del siglo I a. C. Un universo heterogéneo entre la imitación y la estandarización, SPAL 20, 185-283.

GARCIA ROSSELLÓ, J. i GURRI COSTA, E., 1997, Imitacions laietanes d'àmfores itàliques a la zona central de la comarca del Maresme en época tardorepublicana, Annals de l'Institut d'Estudis Gironins 36, 397-424.

GEBELLÍ, P., 2007, El Roquís (Reus, Baix Camp). Una bòbila romana a l'ager de Tàrraco. Poblament rural, producció ceràmica $i$ comerç a les nostres contrades, en època romana, Associació d'Estudis Reusencs, Reus.
GEBELLÍ, P. i JÁRREGA, R., 2010, La terrisseria romana de la Canaleta (Vila-seca), a M. PREVOSTI i J. GUITART (coords.), Ager Tarraconensis. El poblament, Vol. 2, 547-562.

JÁRREGA, R., 1998, La producció amforal romana del Camp de Tarragona. Estat de la qüestió, II Col-loqui Internacional d'Arqueologia Romana. El vi a l'Antiguitat. Economia, producció i comerç al Mediterrani occidental, Monografies Badalonines 14, 430-437.

JÁRREGA, R., 2004, Tarraco Scipionum opus. ¿Escipión Emiliano, fundador de Tarraco?, Butlletí Arqueològic 26, 23-65.

JÁRREGA, R. i ABELA, J., 2011, Producció i importació de ceràmiques a l'ager Tarraconensis. Una aproximació a l'economia del Camp de Tarragona en època romana, a M. PREVOSTI i J. GUITART (eds.), Ager Tarraconensis 2. El poblament, Documenta 16, 141-207.

JÁRREGA, R. i PREVOSTI, M., 2011, Figlinae tarraconenses. La producció ceràmica a l'ager Tarraconensis, a M. PREVOSTI i J. GUITART (eds.), Ager Tarraconensis 2. El poblament, Documenta 16, 455-489.

LÓPEZ MULLOR, A., 2009, Els centres productors d'àmfores de Sant Boi de Llobregat i Darró (Vilanova i la Geltrú), a M. PREVOSTI i A. MARTÍN OLIVERAS (coords.) El vi tarraconense i laietà: ahir i avui, 61-98.

LÓPEZ MULLOR, A., 2013, Las cerámicas de Paredes Finas del final de la República Romana y el período Augusteo-Tiberiano, a A. RIBERA (coord.), Manual de ceràmica romana. Del mundo Helenístico al Imperio Romano, 149-190.

LÓPEZ MULLOR, A. i MARTÍN MENÉNDEZ, A., 2008, Tipologia i datació de les àmfores tarraconenses produïdes a Catalunya, a A. LÓPEZ MULLOR i X. AQUILUÉ ABADÍAS (coords.), La producció $i$ el comerç de les àmfores de la Provincia Hispania Tarraconensis. Homenatge a Ricard Pascual Guasch, Monografies del MAC 8, 33-94.

LÓPEZ VILAR, J. i NOGUERA GUILLÉN, J., 2015, La batalla de Kissa, en Tarragona, a M. BENDALA GALÁN (coord.), Los Escipiones. Roma conquista 
Hispania, Museo Arqueológico Regional, Alcalá de Henares, 301.

LYDING WILL, E., 1982, Greco-Italic Amphoras, Hesperia 51, 338-356.

MARTÍNEZ FERRERAS, V., BUXEDA GARRIGÓS, J. i MARTÍN MENÉNDEZ, A., 2005, L'évolution des premières amphores romaines produites à Cabrera de Mar (Catalogne) d'après leur caractérisation archéométrique, SFECAG, Actes $d u$ Congrès de Blois, 391-401.

MARTÍN MENÉNDEZ, A., 2004, Can Pau Ferrer (Cabrera de Mar, Maresme), Actes de les Jornades d'Arqueologia i Paleontologia, comarques de Barcelona, 1996-2001, 409-422.

MARTÍN MENÉNDEZ, A. i PREVOSTI, M., 2003, El taller d'àmfores de Tomoví i la producció amfòrica a la Cossetània oriental, a J. GUITART, J. M. PALET i M. PREVOSTI (eds.), Territoris antics a la Mediterrània i a la Cossetània oriental. Actes del Simposi Internacional d'Arqueologia del Baix Penedès (el Vendrell, 8-10 de novembre de 2001), 231-237.

MIRÓ, J. i PUJOL, J., 1983, Nota sobre la campanya d'excavacions realitzada durant l'any 1983 en el poblat ibèric de Burriac, Laietania 2-3, 36-41.

MIRÓ, J., PUJOL, J. i GARCÍA ROSELLÓ, J., 1988, El dipòsit del sector occidental del poblat ibèric de Burriac (Cabrera de Mar, el Maresme). Una aportació al coneixement de l'època ibèrica tardana al Maresme (s. I aC), Laietania 4, 7-182.

NOGUERA, J., VALDÉS, P., BLE, E. i LÓPEZ VILAR, J., 2018, Tracing the Roman Republican Army. Military Archaeology in the Northeast of the Iberian Peninsula, a C. S. SOMMER i S. MATESIC (coords.), LIMES XXIII. Proceedings of the $23 r d$ International Congress of Roman Frontier Studies, Ingolstadt, 895-902.

OLESTI, O., 1997, Els primers productors d'àmfores vinícoles al Maresme (s. I a.C.) en Annals de l'Institut d'Estudis Gironins 36, 425-448.

OLESTI, O., 1998, Els inicis de la producción vinícola a Catalunya: el paper del món indígena, II Col-loqui Internacional d'Arqueologia Romana.
El vi a l'Antiguitat. Economia, producció i comerç al Mediterrani occidental, 246-257.

OTIÑA HERMOSO, P. i VERGÈS BOSCH, J. M., 2004, El poblat ibèric del Vilar (Valls, Alt Camp), Butlletí Arqueològic de la RSAT 26, 5-22.

PERA, J., 1994, Una interessant marca d'àmfora Dressel 1 laietana procedent de Santa Eulàlia de Ronçana (Vallès Oriental), Laietania 9, 373-374.

PÉREZ SUÑÉ, J. M. i REVILLA, V., 1997, Sellos ibéricos impresos sobre ánfora, XXIV Congreso Nacional de Arqueología. Impacto colonial y Sureste Ibérico, Vol. 3, 359-366.

RAMON SARIÑENA, E., 2002, Memòria de la intervenció arqueològica realitzada a la zona dels banys de la vil-la romana de l'Eixample el Vilar - C/ Prat de la Riba, Valls (Alt Camp), Memòria d'excavació inèdita, Direcció General del Patrimoni Cultural.

REVILLA, V., 1995, Producción cerámica, viticultura y propiedad rural en Hispania Tarraconensis (siglos I a. C. - III d. C.), Cuadernos de Arqueología 8, Barcelona.

REVILLA, V., 2010, Cultura material y poblamiento en el territorio de Tarraco. Los contextos cerámicos de la villa de Vilarenc (Calafell), a V. REVILLA CALVO i M. ROCA ROUMENS (coords.), Contextos ceràmics $i$ cultura material d'època augustal a l'occident romà. Actes de la reunió celebrada a la Universitat de Barcelona els dies 15 i 16 d'abril de 2007, 198-524.

RUIZ DE ARBULO, J., 2015, Tarraco, obra de los Escipiones y algo más, a M. BENDALA GALÁN (coord.) Los Escipiones. Roma conquista Hispania, $131-147$.

SÁEZ ROMERO, A. i DÍAZ RODRÍGUEZ, J. J., 2007, La producción de ánforas de tipo griego y grecoitálico en Gadir y el área del Estrecho, Zephyrus 60, 195-208.

SOLÉ FOLCH, D., 1996, Interrogants sobre el taller ibèric de Fontscaldes, Quaderns de Vilaniu 29, 109-128.

SOLIER, Y., GUY, M., MORRISSON, C., CHEVALIER, Y., SABRIÉ, M., SABRIÉ, R., BOUSCARAS, A., DEPEYROT, G. I MARICHAL, R., 
1981, Les épaves de Gruissan [sous la direction de Yves Solier], Archaeonautica 3, 7-264.

TCHERNIA, A., 1983, Italian wine in Gaul at the end of the Republic, a P. GARNSEY, K. HOPKINS i C. R. WHITTAKER (eds.), Trade in the Ancient Economy, 87-104.
VERGÈS, J. M., 1995, Memòria de l'excavació arqueológica realitzada al poblat ibèric del Vilar. Direcció General del Patrimoni Cultural. Memòria d'excavació inèdita.

VILA SOCIAS, Ll., 2010, Canvi tecnològic, disseny ceràmic i simulació virtual: el cas de les àmfores romanes, o la mida és realment tan important?, Mayurqa 33, 161-174. 
